\title{
Computational modelling of cambium activity provides a regulatory framework for simulating radial plant growth
}

Ivan Lebovka1, Bruno Hay Mele ${ }^{5}$, Alexandra Zakieva ${ }^{1}$, Nial Gursanscky², Roeland Merks $^{3,4}$, Thomas Greb ${ }^{1 *}$

${ }^{1}$ Centre for Organismal Studies, Heidelberg University, Im Neuenheimer Feld 230, Heidelberg, Germany ${ }^{2}$ Gregor Mendel Institute, Vienna Biocenter, Dr. Bohr-Gasse 3, 1030 Vienna, Austria

${ }^{3}$ Mathematical Institute, University Leiden, P.O. Box 9512, 2300 RA, Leiden, The Netherlands

${ }^{4}$ Institute of Biology, Leiden University, P.O. Box 9505, 2300 RA, Leiden, The Netherlands

${ }^{5}$ Dept. of Agricultural Sciences, Università degli Studi di Napoli Federico II - Reggia di Portici - Via Università, 100 - 80055 - Portici (NA), Italy

Keywords: cambium, radial plant growth, PXY, CLE41, cellular model, VirtualLeaf

${ }^{*}$ Corresponding author, contact: Thomas Greb, Im Neuenheimer Feld 230, 69120 Heidelberg, phone +49-6221-545524, fax +49-6221-54 6424, thomas.greb@cos.uniheidelberg.de 


\section{Abstract}

Precise organization of growing structures is a fundamental problem in developmental biology. In plants, radial growth is mediated by the cambium, a stem cell niche continuously producing wood (xylem) and bast (phloem) in a strictly bidirectional manner. While this process contributes large parts to terrestrial biomass, cambium dynamics eludes direct experimental access due to obstacles in live cell imaging. Here, we present a cell-based computational model visualizing cambium activity and integrating the function of central cambium regulators. Performing iterative comparisons of plant and model anatomies, we conclude that an intercellular signaling module consisting of the receptor-like kinase PXY and its ligand CLE41 constitutes a minimal framework sufficient for instructing tissue organization. Employing genetically encoded markers for different cambium domains in backgrounds with altered PXY/CLE41 activity, we furthermore propose that the module is part of a larger regulatory circuit using the phloem as a morphogenetic center. Our model highlights the importance of intercellular communication along the radial sequence of tissues within the cambium area and shows that a limited number of factors is sufficient to create a stable bidirectional tissue production. 


\section{Introduction}

Stem cells in plants are crucial for their longevity and usually maintained in meristems, special cellular environment constituting maintaining niches [1]. At key positions in the plant body, we find distinct types of meristems that maintain their activity throughout a plant's life cycle. Shoot and root apical meristems (SAM, RAM) are located at the tips of shoots and roots, respectively, driving longitudinal growth and the formation of primary tissue anatomy in these organs. Moreover, lateral meristems organized in cylindrical domains at the periphery of shoots and roots execute their thickening. The cambium is the most prominent among these lateral meristems [2]. Cambium cells are embedded in and produce two distinct vascular tissues in opposite directions by periclinal cell divisions: the xylem (wood) and phloem (bast) [3]. These tissues carry out fundamental physiological functions: long-distance transport of water and nutrients in case of the xylem and translocation of sugars and a multitude of signaling molecules in the case of the phloem. Based on its tightly controlled bidirectionality of tissue production and bipartite organization, the cambium is a paradigm for bifacial stem cell niches found across different kingdoms of life [2, 4]. However, although the cambium plays this instructive role for stem cell biology, a dynamic view on its activity is missing due to its inaccessibility for live cell imaging.

Balancing proliferation and differentiation within meristems is essential. In the SAM and the RAM this balance is maintained via interaction between the pool of stem cells and the organizing center $(\mathrm{OC})$ and the quiescent center $(\mathrm{QC})$, respectively, where the rate of cell division is relatively low. Both domains form a niche within the meristem instructing surrounding stem cells via regulatory feedback loops [5-9]. In comparison to apical meristems, functional characterization of cambium domains was performed 
bioRxiv preprint doi: https://doi.org/10.1101/2020.01.16.908715; this version posted January $17,2020$. The copyright holder for this preprint (which was not certified by peer review) is the author/funder, who has granted bioRxiv a license to display the preprint in perpetuity. It is made available under aCC-BY-NC 4.0 International license.

Lebovka et al.

only very recently. During their passage from stem cells to fully differentiated xylem cells, early xylem cells instruct radial patterning of the cambium including stem cell activity and, thus, similar to the OC in the SAM, fulfil this role only transiently [10]. In addition to influence from the early xylem, phloem-derived DNA-BINDING ONE ZINC FINGER (DOF) transcription factors designated as PHLOEM EARLY DOFs (PEARs) move to cambium stem cells and stimulate their proliferation in a non-cell autonomous manner [11]. Supported by genetically encoded lineage tracing experiments which showed that cell divisions are restricted to a narrow domain, and most likely to individual bifacial stem cells, located in the central cambium [10,12, 13], these findings defined functional cambium domains and started to reveal their reciprocal communication.

Another central and well-established mechanism regulating cambium activity in the reference plant Arabidopsis thaliana and beyond [14-17] is the action of a receptorligand pair formed by the plasma membrane-bound receptor-like kinase PHLOEM INTERCALATED WITH XYLEM (PXY, also known as TDR) and the secreted CLAVATA3/ESR-RELATED 41 (CLE41) and CLE44 peptides. Like the PEAR proteins [11], CLE41 and CLE44 are expressed in the phloem and thought to travel to the dividing cells in the cambium area expressing PXY $[15,18]$. Direct binding of CLE41 to PXY [18-20] promotes the expression of the transcription factor WUSCHEL RELATED HOMEOBOX 4 (WOX4) [21], which, in turn, is crucial for maintaining the capacity of cells to proliferate $[14,21,22]$. At the same time, the PXY/CLE41 module is reported to repress xylem differentiation in a WOX4-independent manner [21, 23]. In this context, PXY stimulates the activity of glycogen synthase kinase 3 proteins (GSK3s), like BRASSINOSTEROID-INSENSITIVE 2 (BIN2) [23]. BIN2, in turn, 
bioRxiv preprint doi: https://doi.org/10.1101/2020.01.16.908715; this version posted January $17,2020$. The copyright holder for this preprint (which was not certified by peer review) is the author/funder, who has granted bioRxiv a license to display the preprint in perpetuity. It is made available under aCC-BY-NC 4.0 International license.

Lebovka et al.

represses the transcriptional regulator BRI1-EMS SUPPRESSOR 1 (BES1), which mediates BR signaling and promotes xylem differentiation [23, 24]. Under the hypothesis of a dual role in regulating stem cell activity and xylem differentiation, PXY is predominantly expressed in the proximal cambium zone oriented toward the xylem containing bifacial cambium stem cells but also cells determined for xylem development $[12,25]$.

Distally to the PXY expression domain-oriented toward the phloem, the closest homolog to PXY, the receptor-like kinase MORE LATERAL GROWTH 1 (MOL1) represses cambium activity [26, 27]. Although their extracellular domains are highly similar, $P X Y$ and MOL1 cannot functionally replace each other, indicating that MOL1 activity does not depend on CLE41/44 peptides and that distinct signaling loops act in the proximal and the distal cambium domain [27]. The latter conclusion is also supported by the finding that the AUXIN RESPONSE FACTOR5 (ARF5) is expressed in the proximal cambium and promotes the transition from stem cells to xylem cells by directly dampening WOX4 activity $[25,28]$. ARF5 activity is enhanced by phosphorylation through the GSK3 BIN2-LIKE 1 (BIL1) which, in contrast to other GSK3s [23], is inhibited by the PXY/CLE41 module [28].

Because the role of several communication cascades between different cambiumrelated tissues is beginning to emerge, it is vital to generate an integrated and dynamic view on their combined impact on cambium activity and patterning. Here, we present a dynamic, cell-based model [29] of the cambium integrating the functions of PXY, CLE41, and putative phloem-derived signals into a modelling framework. Thereby, we are able to reproduce anatomical features of the cambium in a dynamic manner and 
bioRxiv preprint doi: https://doi.org/10.1101/2020.01.16.908715; this version posted January 17,2020 . The copyright holder for this preprint (which was not certified by peer review) is the author/funder, who has granted bioRxiv a license to display the preprint in perpetuity. It is made available under aCC-BY-NC 4.0 International license.

Lebovka et al.

as revealed by informative cambium markers. Our model allows studying the cambium as a dynamic system comprised of multiple interacting factors, and the effects of those factors on cell division, patterning and differentiation. 


\section{Results}

\section{Establishing a dynamic cambium model}

To explore the functional dynamics of cambium activity, we sought to create a dynamic 2D recapitulation of radial plant growth. To do so, we first produced a simplified stereotypic 2D-representation of a plant growth axis displaying a secondary anatomy by employing VirtualLeaf - a framework specially designed for cell-based modeling of plant tissue growth [30]. To avoid confusion, we referred to factors within the model by an asterisk: e.g., GENE - referred to the plant gene, whereas GENE* referred to its model counterpart. Within the model we defined three cell types: Cells designated as cambium ${ }^{*}$, cells present in the center referred to as xylem*, and cells present distally to the cambium* designated as phloem* (Fig. 1A). We then defined rules determining cell $^{*}$ behavior: i) all cells* grew until they reached a size specific for each cell type, ii) cambium cells* divided when they exceeded a certain size, iii) cambium cells* changed their identity into xylem* or phloem* depending on the conditions described below. All chemical-like factors ${ }^{*}$ implemented in the model had manually chosen cell ${ }^{*}$ typespecific production and degradation rates.

To implement context-dependent regulation of cambial cell division and differentiation, we took advantage of the PXY/CLE41 signaling module $[18,21]$. Phloem cells* produced a factor designated as CLE41* able to diffuse passively from cell to cell, whereas cambium cells* produced a non-diffusing factor designated as PXY*. Recapitulating the CLE41-dependent function of PXY, we considered the following reaction:

$$
C L E 41^{*}+P X Y^{*} \rightarrow P X Y_{\text {active }}^{*}
$$


bioRxiv preprint doi: https://doi.org/10.1101/2020.01.16.908715; this version posted January $17,2020$. The copyright holder for this preprint (which was not certified by peer review) is the author/funder, who has granted bioRxiv a license to display the preprint in perpetuity. It is made available under aCC-BY-NC 4.0 International license.

Lebovka et al.

Thereby, the presence of both CLE41* and $\mathrm{PXY}^{*}$ in a cell turned $\mathrm{PXY}{ }^{*}$ into PXYactive*. For cambium cells* we described the PXY*-CLE41* interaction by the following equations:

$\frac{d}{d t}\left[P X Y_{\text {active }}^{*}\right]=\left[P X Y^{*}\right]\left[C L E 41^{*}\right]-$ degradation $_{P X Y_{\text {active }}^{*}} *\left[P X Y_{\text {active }}^{*}\right]$

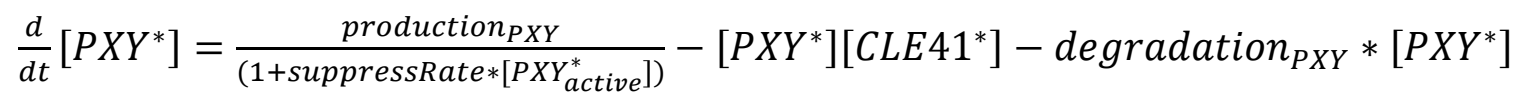

$\frac{d}{d t}\left[{\left.\text { CLE } 41^{*}\right]}^{*}\right.$ diffusion $_{\text {CLE } 41}-\left[P X Y^{*}\right]\left[C L E 41^{*}\right]-$ degradation $_{\text {CLE } 41} *\left[\right.$ CLE $\left._{1} 1^{*}\right]$

In these equations, $[\mathrm{X}]$ denoted the concentration of the respective factor in each cell. Since PXY-CLE41 signaling was reported to negatively regulate PXY expression [15], we assumed that the production rate of $P X Y^{*}$ is inversely dependent on [PXY-active ${ }^{\star}$. Therefore, the higher $\left[\mathrm{PXY}\right.$-active $\left.{ }^{*}\right]$ there was in a given cell ${ }^{*}$, the less $\mathrm{PXY}^{*}$ was produced (equation 3). To integrate PXY/CLE41-dependent regulation of cell proliferation, we let cambium cells* divide only when [PXY-active*] exceeded a certain threshold. Thereby, the proliferation of cambium cells* was dependent on both, locally produced $\mathrm{PXY}{ }^{*}$ and CLE41* produced in the phloem*. To instruct the differentiation of cambium cells*, we took advantage of the observation that the PXY/CLE41 module represses xylem differentiation $[18,23]$. Consequently, we instructed cambium cells* to change their identity into xylem* as soon as they reached a certain size and [PXYactive $\left.^{\star}\right]$ was low.

In the resulting Model 1, the growing structure maintained a circular pool of dividing cambium cells* with a high concentration of PXY-active* while producing xylem cells* toward the center of the organ (Fig. 1B, Movie 1A, Movie 1B, Movie 1C). As expected, 
bioRxiv preprint doi: https://doi.org/10.1101/2020.01.16.908715; this version posted January $17,2020$. The copyright holder for this preprint (which was not certified by peer review) is the author/funder, who has granted bioRxiv a license to display the preprint in perpetuity. It is made available under aCC-BY-NC 4.0 International license.

Lebovka et al.

when cambium cells* were displaced to the proximal side of the cambium*, they stopped dividing likely due to low [PXY-active*] (Fig. 1C, Movie 1C) allowing them to reach a size sufficient for xylem* differentiation. Cell* division rates were highest close to CLE41* producing phloem cells (Fig. 1C-F, Movie 1B, Movie 1C). Moreover, as expected due to the negative effect of PXY-active* on the production of $P X Y^{*},\left[P X Y^{*}\right]$ was particularly low in the distal cambium* region (Movie $1 \mathrm{~A}, \mathrm{Fig} .1 \mathrm{~B}, \mathrm{E}, \mathrm{F}$ ). This pattern was reminiscent of the exclusive activity of the PXY promoter in the proximal cambium area observed previously $[12,27]$. Thus, although phloem was not produced, with maintaining a circular domain of cambium cells* and cell* proliferation and with promoting xylem* production, Model 1 was able to recapitulate several central features of the active cambium.

The combination of $P X Y$ and SMXL5 promoter reporters visualizes cambium anatomy

To identify rules for phloem formation, we took advantage of findings obtained using the PXYpro:CYAN FLUORESCENT PROTEIN (PXYpro:CFP) and SUPPRESSOR OF MAX2-LIKE 5pRO:YELLOW FLUORESCENT PROTEIN (SMLX5pro:YFP) markers, recently established read-outs for cambium anatomy [12]. PXYpro:CFP and SMXL5pro:YFP markers label the proximal and distal cambium domain, respectively, and are therefore indicative of the bipartite cambium organization [12]. A transgene expressing the fluorescent mCherry protein under the control of the Histone 4 promoter (H4pro:mCherry) as an approximate marker for cell divisions [31, 32], confirmed similar rates of cell proliferation along both domains [12] and revealed that H4pro:mCherry positive cells are present equally in PXYpro:CFP and SMXL5pro:YFP positive regions with the center of activity at the interface of both domains (Fig. 2E and F, Fig. S1). 
To computationally recapitulate the observed pattern of cell division rates, we introduced a factor inhibiting cell* divisions in the distal layers of the cambium*. Such a factor was reminiscent of the receptor-like kinase MOL1 which, similarly to SMXL5, is expressed distally to $P X Y$ expressing cells and suppresses cambial cell divisions [27]. Because cells* in the distal cambium* region were characterized by high levels of PXY-active* (Fig. 1B, D), we used this positional feature to introduce a local inhibition of cell* division and, at the same time, to instruct phloem* formation. Therefore, we modified the rule for cell ${ }^{\star}$ differentiation such that when a cambium cell ${ }^{*}$ reached a specific size, it differentiated into xylem* if [PXY-active*] was low and into phloem* when [active-PXY*] was high. Thereby, our model followed a classical 'French flag' principle of development according to which concentration gradients of diffusible morphogens pattern surrounding tissues [33]. It is worth noting that the combined effect of CLE41* on cell* proliferation, on phloem* specification and on $\left[\mathrm{PXY}{ }^{*}\right]$ may also be achieved by distinct phloem-derived factors mediating these effects individually.

Computational implementation of these rules (Model 2A) resulted in a descending gradient of cell* division rates in the distal cambium* domain likely due to high levels of PXY-active* (Fig. 3A-D, Movie 2A, Movie 2B, Movie 2C). The cell* division rate was highest in the proximal cambium* domain defined by high [PXY*] (Fig. 3D, Movie 2D). Also, not only xylem* but also phloem* was continuously produced and the fate of cambium cells* was dependent on their position relative to the differentiated tissues*. In the central cambium* domain cells* proliferated and constantly replenished the stem cell pool (Figure 3B, Movie 2A, Movie 2B, Movie 2C). Thus, by incorporating relatively simple rules, Model $2 \mathrm{~A}$ was able to recapitulate major cambium features, including 
bioRxiv preprint doi: https://doi.org/10.1101/2020.01.16.908715; this version posted January 17,2020 . The copyright holder for this preprint (which was not certified by peer review) is the author/funder, who has granted bioRxiv a license to display the preprint in perpetuity. It is made available under aCC-BY-NC 4.0 International license.

Lebovka et al.

phloem formation. Moreover, in qualitative terms, the resulting anatomy* reproduced the anatomy of a mature Arabidopsis hypocotyl (Fig. 3A, B).

\section{Model of cambium dynamics offers an explanation for the effect of ectopic CLE41 expression}

To estimate the predictive power of Model 2, we tested its capacity to simulate the effects of experimental perturbation of cambium regulation. Ectopic expression of CLE41 by employing the IRREGULAR XYLEM 3/CELLULOSE SYNTHASE CATALYTIC SUBUNIT 7 (IRX3/CESA7) promoter which is active in cells undergoing secondary cell wall deposition [34-36] substantially alters hypocotyl anatomy [15]. This effect was confirmed when PXYpro:CFP/SMXL5pro:YFP activities were analyzed in a plant line carrying also an IRX3pro:CLE41 transgene (Fig. 4A). The PXYpro:CFP activity domain had a cylindrical shape surrounding the xylem in plants with a wild type background (Fig. 3A), while in the presence of the IRX3pro:CLE41 transgene, PXYpro:CFP activity surrounded a reduced overall number of differentiated xylem cells and was present in irregularly shaped patches distributed over the whole cross-section (Fig. 4A). Moreover, we observed regions without PXYpro:CFP activity in proximal hypocotyl regions where SMXL5pro:YFP was active (Fig. 4A). Besides, a substantial part of SMXL5pro:YFP activity was detected in the distal regions of the hypocotyl forming islands of irregular shape sometimes intermingled with PXYpro:CFP activity (Fig. 4A). This activity pattern was in contrast to the one found in plants without the IXR3pro:CLE41 transgene where SMXL5pro:YFP reporter activity surrounded the PXYpro:CFP expression domain only from the distal side (Fig. 3A). These results indicated that not only the radial anatomy of the hypocotyl [15] but also the cambium organization itself depends on the site of CLE41 production. 
For a computational simulation of the effect of the IRX3pro:CLE41 transgene, we instructed xylem cells* to produce CLE $41^{*}$ at the same rate as phloem* cells (Model 2B). Although in this case xylem* formation was initially repressed possibly due to high levels of PXY-active* in all cambium* cells (Fig. 4B, Movie 3A, Movie 3B, Movie 3C), new xylem* cells were formed as soon as the distance between existing xylem and phloem cells became large enough such that CLE41* levels and, in turn, PXY-active* dropped to permissive levels (Fig. 4C, Movie 3A, Movie 3B, Movie 3C). New phloem cells were produced close to existing phloem* and xylem* cells likely due to high levels of PXY-active* (Fig. 4C, Movie 3D). As a result, Model 2B produced a similar disruption in cambium* organization, as observed in IRX3pro:CLE41 plants (Movie 3A, Movie 3B, Movie 3C, Fig. 4D). Zones with both high [PXY-active*] and low [PXY*], which were found in the distal cambium* in Model 2A (Fig. 3B), appeared in the organ* center together with individual xylem cells* (Fig. 4D). Moreover, in addition to being produced in distal regions, new phloem cells* were produced in the central areas of the organ* as demonstrated previously for IXR3pro:CLE41 plants [15]. Thus, rules determining cambium* polarity implemented in Model 2 were sufficient to partly simulate organ anatomy found in wild type and IXR3pro:CLE41 genetic backgrounds.

However, a discrepancy between model structure and the in planta situation was suggested when we compared a model with reduced PXY* activity with pxy mutants carrying the PXYpro:CFP and SMXL5pro:YFP reporters. In pxy mutants the xylem tissue did not have a cylindrical shape, but was instead clustered in radial sectors showing PXYpro:CFP and SMXL5pro:YFP activity at their distal ends, whereas regions in between those sectors had little to no xylem (Fig. 4E). PXY promoter reporter activity 
bioRxiv preprint doi: https://doi.org/10.1101/2020.01.16.908715; this version posted January $17,2020$. The copyright holder for this preprint (which was not certified by peer review) is the author/funder, who has granted bioRxiv a license to display the preprint in perpetuity. It is made available under aCC-BY-NC 4.0 International license.

Lebovka et al.

was observed distally to xylem sectors, whereas the SMXL5 promoter activity was as usual present distally to the PXY activity domain. Interestingly, the radial dimension of the PXYpro:CFP expression domain was not expanded in relation to the SMXL5pro:YFP domain and both domains were still completely distinct (Fig. 4E). This discrepancy indicated that, in contrast to our assumption, the CLE41-PXY signaling module did not restrict $P X Y$ promoter activity in the distal cambium. The discrepancy between Model 2 and the situation in plants was confirmed when we completely eliminated $\mathrm{PXY}^{*}$ activity from our model (Model 2C). As expected, this resulted in the absence of growth due to the full dependence of cell ${ }^{*}$ divisions on the $P X Y^{*}$ function, clearly being at odds with the phenotype of pxy mutants (Fig. 4E). Even a computational reduction of $\mathrm{PXY}^{*}$ activity (Model 2D) did not result in a split of the continuous cambium domain* but abolished phloem* formation and increased the production of xylem (Fig. 4F). Also, in contrast to the situation in the pxy mutant, the size ratio of the $P X Y^{*}$ and active-PXY* domains was increased under conditions with reduced $\mathrm{PXY}^{*}$ activity (Fig. 4E, F). Moreover, quantification of xylem vessels, xylem fibers and xylem parenchyma in sections from wild type and pxy mutant hypocotyls by automated image segmentation revealed that the total number of xylem cells and the number of xylem vessels was comparable (Fig. 4G-I). In contrast, the number of cells classified as fibers was substantially reduced in pxy mutants whereas the number of cells classified as parenchyma was increased (Fig. 4G-I). These results suggested that during radial growth, $P X Y$ promotes the formation of xylem fibers, while the formation of xylem vessels and the total number of cambium-derived cells produced proximally is hardly $P X Y$-dependent. 
bioRxiv preprint doi: https://doi.org/10.1101/2020.01.16.908715; this version posted January $17,2020$. The copyright holder for this preprint (which was not certified by peer review) is the author/funder, who has granted bioRxiv a license to display the preprint in perpetuity. It is made available under aCC-BY-NC 4.0 International license.

Lebovka et al.

\section{Multiple phloem-derived factors determine cambium activity}

Our observations prompted us to reconsider some features of our model and to extend the 'French flag' approach. Because the production rate of cells produced proximally by the cambium was not $P X Y$-dependent, we made xylem* formation independent from the control of PXY-active*. Instead, cambium cells* differentiated into xylem* cells when they reached a specific size and, at the same time, expressed $P X Y^{*}$ as a positional feature. To allow maintenance of active cambium cells* in the absence of $\mathrm{PXY}^{*}$, we introduced a second phloem*-derived factor $(\mathrm{PF})$, reminiscent of the PEAR transcription factors identified recently [11]. PF stimulated cell* divisions by promoting the production of a division factor (DF) in cambium cells* and in phloem parenchyma* (Fig. 5A, see below). Cambium cells divided only if the concentration of DF exceeded a threshold value. DF production was at the same time stimulated by PXY-active* as its only effect in cambium cells (Fig. 5A). Thereby, cambial cell* divisions were dependent on the combined influence of PXY-active* and their proximity to phloem poles.

DF production was, thus, determined as follows:

$$
\frac{d}{d t}[D F]=\text { diffusion }_{D F}+\frac{\text { production }_{D F} *[\text { Stimuli }]}{(k+[P F *]+[P X Y-\text { active }])}-\text { degradation }_{D F}
$$

Where $\mathrm{k}$ stands for an empirically defined coefficient.

Based on the strong association of xylem sectors with developing phloem cells (Fig. $4 \mathrm{E})$, we further hypothesized that the formation of those sectors in pxy mutants was dependent on the heterogeneity of cell type distribution in the phloem. Therefore, 
bioRxiv preprint doi: https://doi.org/10.1101/2020.01.16.908715; this version posted January 17,2020 . The copyright holder for this preprint (which was not certified by peer review) is the author/funder, who has granted bioRxiv a license to display the preprint in perpetuity. It is made available under aCC-BY-NC 4.0 International license.

Lebovka et al.

phloem cells* from the previous models were split into two cell types - phloemparenchyma* and phloem-poles* (Fig. 5A). To achieve the dispersed pattern of phloem poles, cambium*-derived cells* fulfilling the criteria to differentiate into phloem (see above), differentiated into phloem poles by default, unless inhibited by PF, which was specifically produced in pole cells*. Thereby, phloem-poles* suppressed phloem-pole* formation in their vicinity, expected to result in a patchy pattern of phloem poles as observed in planta [37]. It is worth noting that CLE41* was still produced in both phloem poles $^{*}$ and phloem parenchyma* but with a higher rate in phloem poles*. To further achieve $P X Y^{*}$-independent cambium subdomain separation, phloem-parenchyma* and phloem-poles* were set to express another diffusive signal (RP) which suppressed $\mathrm{PXY}^{*}$ expression in cambium* cells, the role that was played by $\mathrm{PXY}$-active* before (Fig. 5A). Importantly, cell divisions in the distal cambium were not actively repressed anymore but were exclusively dependent on cell size and the level of DF.

Computational application of these principles (Model $3 \mathrm{~A}$ ) resulted again in the establishment of two cambium* subdomains - the distal subdomain which was characterized by high concentrations of DF and the proximal subdomain characterized by high $\mathrm{PXY}^{*}$ concentration (Fig. 5B-D, Movie 4A, Movie 4B). Distally, the cambium* produced phloem-parenchyma* cells from which phloem-poles* were continuously formed with a pattern resembling the patchy phloem pattern observed in plants (Fig. 5B) [37]. Interestingly, the localization of PF production mainly in phloem poles* resulted in increased DF levels in the vicinity of those poles and, as expected, in locally increased cell* division rates (Movie 4C, Movie 4D). This observation was reminiscent of the activity of the cell division marker H4pro:mCherry in patches of cells distally to 
bioRxiv preprint doi: https://doi.org/10.1101/2020.01.16.908715; this version posted January $17,2020$. The copyright holder for this preprint (which was not certified by peer review) is the author/funder, who has granted bioRxiv a license to display the preprint in perpetuity. It is made available under aCC-BY-NC 4.0 International license.

Lebovka et al.

the immediate cambium area where also the SMXL5pro:YFP reporter was active and which presumably contained developing phloem cells (Fig. S1).

By instructing CLE41* production also in xylem cells*, we simulated CLE41misexpression by the IRX3 promoter (Model 3B, Movie 5A, Movie 5B, Movie 5C, Movie 5D, Fig. 5E). CLE41* interacted with $\mathrm{PXY}^{*}$ on the proximal cambium* border, which resulted in ectopic DF production and phloem-parenchyma* formation in the proximal hypocotyl* regions (Fig. 5E). Still, xylem cells* were formed, generating a patchy xylem* pattern resembling the xylem configuration found in IRX3pro:CLE41 plants (Movie 5A, Fig. 4A, Fig. 5E). Eliminating PXY* (Model 3C) generated a patchy outline of the distal cambium* subdomain (Movie 6A, Movie 6B, Movie 6C, Movie 6D, Fig. 5F) likely because in cambium cells* at a certain distance from phloem poles* ${ }^{*} \mathrm{PXY}^{*}$ was usually the main trigger of cell ${ }^{*}$ divisions whereas PF was also influential next to phloem poles*. Thus, by introducing both a $P X Y^{*}$-independent pathway stimulating cambium$^{*}$ proliferation and dependence of cell ${ }^{*}$ proliferation on the distance to phloem poles $^{*}$, we were able to simulate important features of the pxy mutant phenotype (Fig. 4E, Fig. 5F). Collectively, we concluded that we established a cambium model with sufficient power and robustness to simulate major genetic perturbations of cambium regulation.

To incorporate realistic tissue ratios and unbiased parameter identification, we next performed an automated parameter search using a previous characterization of Arabidopsis hypocotyl anatomy [37] as a criterion for parameter selection. To this end, we instructed our search algorithm to aim for a tissue ratio of 20,15 and $65 \%$ for cambium* $^{*}$ xylem*, and phloem cell ${ }^{*}$ number, respectively. Performing 4000 
bioRxiv preprint doi: https://doi.org/10.1101/2020.01.16.908715; this version posted January 17,2020 . The copyright holder for this preprint (which was not certified by peer review) is the author/funder, who has granted bioRxiv a license to display the preprint in perpetuity. It is made available under aCC-BY-NC 4.0 International license.

Lebovka et al.

simulations resulted in a set of parameters (Table S1) producing a more realistic tissue anatomy than we achieved by our manually selected set before (Fig. 5G). Thus, by taking real tissue anatomy as a guideline, we were able to establish a model with a more realistic outline. 


\section{Discussion}

Growth and development of multicellular organisms are complex non-linear processes whose dynamics and network properties are not possible to predict only based on information on their individual building blocks and their one-to-one interactions. The rather simple cellular outline along the radial axes of organs, growth in only two dimensions, and the recent identification of central functional properties [10-12], make radial plant growth an attractive target for a systematic approach to reveal its intriguing dynamics. Here, we developed a computational representation of radial plant growth using the VirtualLeaf framework [30] which can recapitulate fundamental features of this process and integrates the PXY/CLE41 module as one central element for cambium patterning and maintenance of tissue domains.

Using positional information mediated by morphogenetic gradients of diffusible chemicals to pattern growing structures is a classical concept in developmental biology $[33,38,39]$. In a first approach, we used the PXY/CLE41 module to generate such a gradient instructing cambium cells* to differentiate into xylem cells*, to proliferate or to differentiate into phloem cells*. Repression of cell division in the distal cambium was achieved by implementing an adverse effect of PXY-signaling* on $\mathrm{PXY}^{*}$ production. Together, this setup was able to maintain stable radial tissue organization during radial growth and established a maximum of cell division rates in the cambium center as observed by experimental means [12]. Thus, we conclude that cambium organization and radial patterning of plant growth axes can be maintained by a distinct pattern of radially acting morphogens. Such a role was initially proposed for auxin whose differential distribution, however, seems to be rather a result of tissue patterning than being instructive [40]. 
In contrast to our expectations, though, the amount of proximal tissue production during radial plant growth did not depend on the function of $P X Y$. Automated image analysis including object classification revealed that neither the number of cells produced toward the organ center nor the number of vessel elements did change in a pxy mutant background but rather the ratio between parenchyma and fiber cells. Therefore, in contrast to a negative effect of PXY/CLE41 signaling on vessel formation in vascular bundles in leaves $[18,23]$, vessel formation during radial plant growth is PXY/CLE41-independent. Instead, fiber formation is positively associated with the PXY/CLE41 module. These observations indicated that xylem formation is unlikely to be instructed by PXY/CLE41 signaling alone but that additional signals are required.

Moreover, the application of markers visualizing cambium organization showed that $P X Y$-deficiency leads to the absence of an organized cambium in some regions of the hypocotyl whereas in other areas, the cambium is maintained. Since such areas are regularly spaced, factors acting in parallel to PXY/CLE41 also carrying spatial information may be responsible for this pattern. Although ethylene signaling was reported to fulfill the first criterion, spatial specificity does not seem to be a characteristic property of ethylene signaling [41]. In contrast, PEAR transcription factors are phloem-derived and stimulate the proliferation of cambium stem cells presumably in a PXY/CLE41-independent manner [11] and, thus, may act similarly to the $\mathrm{PF}^{*}$ factor we introduced in our model. The ERECTA/ EPIDERMAL PATTERNING FACTOR-LIKE (ER/EPFL) receptor-ligand pathway acting in concert with the PXY/CLE41 module [42, 43] represents another candidate for playing such a role. In addition, CLE45 was recently proposed to be expressed in developing sieve elements, 
bioRxiv preprint doi: https://doi.org/10.1101/2020.01.16.908715; this version posted January 17,2020 . The copyright holder for this preprint (which was not certified by peer review) is the author/funder, who has granted bioRxiv a license to display the preprint in perpetuity. It is made available under aCC-BY-NC 4.0 International license.

Lebovka et al.

the conducting units of the phloem, and repress the establishment of sieve element identity in their immediate environment [44]. The $\mathrm{PF}^{*}$ factor in our model combines features of these phloem-derived molecules.

In addition to the phloem sending out instructive signals, early xylem cells have been identified recently to act as an organizing center of cambium patterning [10]. Although this finding seems to be at odds with our claim that phloem-derived signals are sufficient for cambium organization, it is important to consider that we, for example, ignored upstream regulation of postulated factors like PXY* or CLE41* which obviously depends on positional information. Thus, reciprocal and interconnected gradients of regulators along the radial sequence of tissues may be essential for establishing and maintaining cambium organization, including xylem-derived signals.

In this context, it is interesting to note that we deliberately excluded the transition from the initially bisymmetric tissue conformation to a concentric tissue organization as occurring in hypocotyls and roots $[10,37]$ from our simulations. Our rationale was that the rather complex change in tissue anatomy during the transition from a primary to a secondary conformation in the hypocotyl required more assumptions in our model and would have spoiled the advantages of a relatively simple anatomy for generating a cellbased computational model. Moreover, the differences in primary anatomy of shoots and roots before the onset of radial plant growth $[10,32]$ would have required different cellular outlines for both cases and, thus, would have hampered the generality of our approach. Interestingly, when starting with a concentric anatomy of tissues, the circular shape of the organ* was maintained and no additional mechanism ensuring organ circularity had to be postulated. The maintenance of the circularity of the entire organ* 
bioRxiv preprint doi: https://doi.org/10.1101/2020.01.16.908715; this version posted January $17,2020$. The copyright holder for this preprint (which was not certified by peer review) is the author/funder, who has granted bioRxiv a license to display the preprint in perpetuity. It is made available under aCC-BY-NC 4.0 International license.

Lebovka et al.

during its expansion was an emerging property of a radial domain of cell* proliferation. However, it is likely that more peripheral tissues like the epidermis or the periderm [45], which we did not consider in our model, influence organ shape in planta.

We envision that the model presented in this study allows recapitulating qualitative and quantitative variation in radial plant growth found in different mutants and when comparing different dicotyledonous species [46]. Remarkable features like the establishment of concentric cambium rings often found in the order of Caryophyllales [47] or 'phloem wedges' found, among others, in the Bignonieae genus [48] may be recapitulated by modifying parameters chosen in the model or by the invention of novel factors. Moreover, the model may help to predict targets of environmental stimuli inducing changes of cambium activity like seasonal changes [49] or mechanical perturbation [50], allowing the generation of testable hypotheses. Thus, our dynamic model will be a useful tool for investigating a process not possible to observe in real time and partly develops over exceptionally long periods. 


\section{Material and Methods}

\section{Plant material and growth conditions}

Arabidopsis thaliana (L.) Heynh. plants of Columbia-0 accession were used for all experiments and grown as described previously [22]. pxy-4 (SALK_009542, N800038) mutants were ordered from the Nottingham Arabidopsis Stock Centre (NASC). Plant lines carrying IRX3pro:CLE41 and 35Spro:CLE41 transgenes [15] were kindly provided by Peter Etchells (Durham University, UK). PXYpro:ECFP-ER (pPS19) and SMXL5pro:EYFP-ER (pJA24) reporter lines were described previously [51, 52].

\section{Generation of the H4pro:mCherry transgene}

The H4pro:mCherry-ER (pMS77) vector was generated using pGreen0029 [53] as a backbone. The 5' and 3' promoter regions of the $\mathrm{H} 4$ gene were first amplified using genomic DNA as a template using the primers H4for2/H4rev2 (5'actaggtacctagtttgtgctgcaagtgacac-3'/5'-actagaattctgatg cattttcagcgaagatttagtttatc-3')

and H4for3/H4for3 (5'- actactgcagttagagttttcagatccgcg-3'/5'actagcggccgcaaagcgatgataaattggaac-3'), respectively. The resulting DNA fragments were cloned into Kpnl/Notl restriction sites of pGreen0029 resulting in pMS76. Next, the mCherry reporter sequence was fused to target signals for the endoplasmatic reticulum [54] and cloned into Nsil/Pstl sites generated between the two promoter fragments. 


\section{Confocal microscopy}

Confocal microscopy of hypocotyls was performed as described before [22]. Hypocotyls were isolated and cleaned from surrounding leaf material using razor blades (Classic Wilkinson, Germany). The cleaned hypocotyls were mounted in $7 \%$ low melting point agar (Sigma-Aldrich, St. Louis, MO, USA) in water and $200 \mu \mathrm{m}$ sections were taken using a vibratome (Leica VT1000 S). For analyzing the fluorescent markers, the following microscopes were used: LSM 880, LSM 780 microscope (Zeiss, Germany) and Leica SP5 (Germany). Different fluorescence protein signals were collected in different tracks. YFP was excited at $514 \mathrm{~nm}$ and emission was collected at 522-542 $\mathrm{nm}$. CFP was excited at $458 \mathrm{~nm}$ and the signal emission was collected at 469$490 \mathrm{~nm}$. The propidium iodide-derived signal was excited at $561 \mathrm{~nm}$ and emission was detected at $620-670 \mathrm{~nm}$. mCherry was excited at $561 \mathrm{~nm}$ and emission was detected at $600-650 \mathrm{~nm}$.

\section{Histology}

Histological analyses of the stem were performed as described previously [51]. All samples whose histology was compared were grown in parallel.

\section{llastik cell type counting}

The xylem area was cropped manually from histological images of wild type and pxy mutant. The llastik toolkit [55] was used for image segmentation and cell type classification (https://www.ilastik.org). With a training set, the pixel classification workflow was trained to distinguish cell walls from the background. After segmentation, the object classifier was then trained to split the resulting objects into four groups xylem vessels, xylem fibers, xylem parenchyma, and unclassified objects. The 
bioRxiv preprint doi: https://doi.org/10.1101/2020.01.16.908715; this version posted January $17,2020$. The copyright holder for this preprint (which was not certified by peer review) is the author/funder, who has granted bioRxiv a license to display the preprint in perpetuity. It is made available under aCC-BY-NC 4.0 International license.

Lebovka et al.

resulting classifier was then applied to all cropped images. For each image, cell type data were extracted using python.

\section{VirtualLeaf simulations}

Simulations were performed as recommended previously [30]. To be able to see established models in action, the VirtualLeaf software was installed according to the following instructions described in the supplementary information and as described previously [56]. All simulations within Model 1, Model 2, and Model 3, respectively, were conducted for the same VirtualLeaf time duration. For each of the models described in this paper, we provide code files in the "model_codes" folder found at https://github.com/kergakerga/cambium models.

\section{Splitting the result of VirtualLeaf simulations into bins}

After a VirtualLeaf simulation was completed, the resulting $\mathrm{xml}$ template was stored. To analyze the distribution of chemicals* in such a template along the radial axis, we produced a python script named "Cambium_bins_calculation.ipnb". Within the script, it was possible to indicate the path to the $\mathrm{xml}$ file, and the script produced two .csv files - one with a table containing data about each cell and another with information about averages across the requested bin number.

\section{Parameter optimization}

In order to optimize the parameters of our model we took advantage of the "Hyperopt" python library [57]. To extract cell numbers in each tissue after each simulation, we built a python script able to run VirtualLeaf simulations automatically using a distinct set of parameters as input. After every simulation, the script counted the number of cells belonging to each cell type and computed their relative proportion. To use 
bioRxiv preprint doi: https://doi.org/10.1101/2020.01.16.908715; this version posted January $17,2020$. The copyright holder for this preprint (which was not certified by peer review) is the author/funder, who has granted bioRxiv a license to display the preprint in perpetuity. It is made available under aCC-BY-NC 4.0 International license.

Lebovka et al.

Hyperopt, we needed to design a score function and the parameter space. The score function should contain information about the optimization goals - during the parameter search, Hyperopt will attempt to minimize this function. The parameter space contains an interval for each parameter from which the parameter value can be chosen. Based on in planta observations [37], we defined that the simulation should result in $20 \%$ cambium, $15 \%$ xylem, and $65 \%$ phloem cells. Thus, we created this score function: $(c-20)^{2}+(x-15)^{2}+(p-65)^{2}+(t / 3000 * 100)^{2}$, where $c, x$, and $p$ were the relative amount of cambium, xylem, and phloem cells, respectively. We added the total number of cells (t) to the score function to encourage model growth during the parameter search. This function had lower values when the result of a simulation was closer to the desired issue proportions. To define the parameter search space, we used parameter values found during the model creation procedure. We designed a search space for each parameter around the value which was manually found using the following criterion: Manually found Value / $3<$ Search space values $<$ Manually found Value * 3 . As we were interested in obtaining simulations with an active cambium we discarded

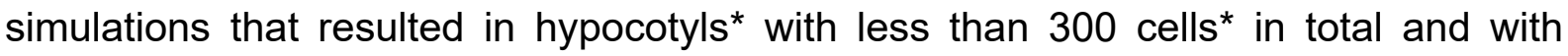
cambium cells less than 30 . 
bioRxiv preprint doi: https://doi.org/10.1101/2020.01.16.908715; this version posted January 17, 2020. The copyright holder for this preprint (which was not certified by peer review) is the author/funder, who has granted bioRxiv a license to display the preprint in perpetuity. It is made available under aCC-BY-NC 4.0 International license.

Lebovka et al.

\section{Acknowledgements}

We thank Peter Etchells (Durham University, UK) for providing seed material, Karin Grünwald and Martina Laaber-Schwarz (both GMI, Vienna, Austria) for technical assistance and Dongbo Shi, Eva-Sophie Wallner and Vadir López-Salmerón for comments on the experimental strategy and the manuscript. We also thank Claudiu Antonovici (University of Leiden, The Netherlands) for help in setting up the VirtualLeaf platform. This work was supported by the Deutsche Forschungsgemeinschaft (DFG) through the Research Unit FOR2581 'Plant Morphodynamics, grant GR2104/4-1 and a Heisenberg Professorship (GR2104/5-2) to T.G.. The work by B.H.M. was initiated at Centrum Wiskunde \& Informatica (CWI), Amsterdam, The Netherlands. R.M. and B.H.M. thank CWI for providing a CWI Internship to B.H.M. and for hosting I.L..

\section{Author Contributions}

Conceived and designed the experiments: IL, BHM, RM, TG. Performed the experiments: IL, BHM, AZ, NG. Analysed the data: IL, BHM, AZ. Wrote the paper: IL, TG.

\section{Conflict of Interest}

The authors have no conflicts of interest to declare. 


\section{Supplementary Information Items}

Figure S1: Visualization of $H 4$ promoter activity within cambium subdomains

Table S1: Parameter values and chemicals

Supplementary Methods: Instructions for implementing VirtualLeaf models

Movie 1A: Model 1 output, visualizing xylem (red) and phloem (purple), and accumulation of $\mathrm{PXY}^{*}$ (blue) and PXY-active* (green)

Movie 1B: Model 1 output, visualizing CLE41* (yellow) accumulation

Movie 1C: Model 1 output, visualizing cell divisions (red)

Movie 2A: Model 2A output, visualizing xylem (red) and phloem (purple), and accumulation of $\mathrm{PXY}^{*}$ (blue) and PXY-active* (green)

Movie 2B: Model 2A output, visualizing CLE41* (yellow) accumulation

Movie 2C: Model 2A output, visualizing cell divisions (red)

Movie 2D: Model 2A output, visualizing cell divisions (red) together with PXY* (blue) and PXY-active* (green) accumulation

Movie 3A: Model 2B output, visualizing xylem (red) and phloem (purple), and accumulation of $\mathrm{PXY}^{*}$ (blue), and PXY-active* (green)

Movie 3B: Model 2B output, visualizing CLE41* (yellow) accumulation

Movie 3C: Model 2B output, visualizing cell divisions (red)

Movie 3D: Model 2B output, visualizing accumulation of $P X Y^{*}$ (blue) and PXY-

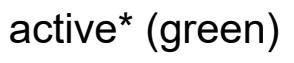


Movie 4A: Model 3A output, visualizing xylem (red), phloem parenchyma (light purple), and phloem poles (dark purple), and accumulation of PXY* (blue) and the devision chemical (DF)* (green)

Movie 4B: Model 3A output, visualizing CLE41* (yellow) accumulation

Movie 4C: Model 3A output, visualizing cell divisions (red)

Movie 4D: Model 3A output, visualizing accumulation of $\mathrm{PXY}^{*}$ (blue) and the devision chemical (DF)* (green)

Movie 5A: Model 3B output, visualizing xylem (red), phloem parenchyma (light purple), and phloem poles (dark purple), and accumulation of PXY* (blue) and the devision chemical (DF)* (green)

Movie 5B: Model 3B output, visualizing CLE41* (yellow) accumulation

Movie 5C: Model 3B output, visualizing cell divisions (red)

Movie 5D: $\quad$ Model 3B output, visualizing accumulation of $P X Y^{*}$ (blue) and the devision chemical (DF)* (green)

Movie 6A: Model 3C output, visualizing xylem (red), phloem parenchyma (light purple), and phloem poles (dark purple), and accumulation of $\mathrm{PXY}$ * (blue) and the devision chemical (DF)* (green)

Movie 6B: Model 3C output, visualizing CLE41* (yellow) accumulation

Movie 6C: Model 3C output, visualizing cell divisions (red)

Movie 6D: Model 3C output, visualizing accumulation of $\mathrm{PXY}^{*}$ (blue) and the devision chemical (DF)* (green) 


\section{Literature}

1. Greb, T., and Lohmann, J.U. (2016). Plant Stem Cells. Current biology : CB 26, R816-821.

2. Fischer, U., Kucukoglu, M., Helariutta, Y., and Bhalerao, R.P. (2019). The Dynamics of Cambial Stem Cell Activity. Annual review of plant biology 70, 293-319.

3. Chiang, M.H., and Greb, T. (2019). How to organize bidirectional tissue production? Curr Opin Plant Biol 51, 15-21.

4. Shi, D., Tavhelidse, T., Thumberger, T., Wittbrodt, J., and Greb, T. (2017). Bifacial stem cell niches in fish and plants. Current opinion in genetics \& development 45, 28-33.

5. Sabatini, S., Heidstra, R., Wildwater, M., and Scheres, B. (2003). SCARECROW is involved in positioning the stem cell niche in the Arabidopsis root meristem. Genes Dev 17, 354-358.

6. Sarkar, A.K., Luijten, M., Miyashima, S., Lenhard, M., Hashimoto, T., Nakajima, K., Scheres, B., Heidstra, R., and Laux, T. (2007). Conserved factors regulate signalling in Arabidopsis thaliana shoot and root stem cell organizers. Nature 446, 811-814.

7. Mayer, K.F., Schoof, H., Haecker, A., Lenhard, M., Jurgens, G., and Laux, T. (1998). Role of WUSCHEL in regulating stem cell fate in the Arabidopsis shoot meristem. Cell 95, 805-815.

8. Daum, G., Medzihradszky, A., Suzaki, T., and Lohmann, J.U. (2014). A mechanistic framework for noncell autonomous stem cell induction in Arabidopsis. Proceedings of the National Academy of Sciences of the United States of America 111, 14619-14624.

9. Pi, L., Aichinger, E., van der Graaff, E., Llavata-Peris, C.I., Weijers, D., Hennig, L., Groot, E., and Laux, T. (2015). Organizer-Derived WOX5 Signal Maintains Root Columella Stem Cells through Chromatin-Mediated Repression of CDF4 Expression. Developmental cell 33, 576-588.

10. Smetana, O., Makila, R., Lyu, M., Amiryousefi, A., Sanchez Rodriguez, F., Wu, M.F., Sole-Gil, A., Leal Gavarron, M., Siligato, R., Miyashima, S., et al. (2019). High levels of auxin signalling define the stem-cell organizer of the vascular cambium. Nature 565, 485-489.

11. Miyashima, S., Roszak, P., Sevilem, I., Toyokura, K., Blob, B., Heo, J.O., Mellor, N., Help-RintaRahko, H., Otero, S., Smet, W., et al. (2019). Mobile PEAR transcription factors integrate positional cues to prime cambial growth. Nature $565,490-494$.

12. Shi, D., Lebovka, I., Lopez-Salmeron, V., Sanchez, P., and Greb, T. (2019). Bifacial cambium stem cells generate xylem and phloem during radial plant growth. Development (Cambridge, England) 146, dev171355. 
13. Bossinger, G., and Spokevicius, A.V. (2018). Sector analysis reveals patterns of cambium differentiation in poplar stems. Journal of experimental botany 69, 4339-4348.

14. Kucukoglu, M., Nilsson, J., Zheng, B., Chaabouni, S., and Nilsson, O. (2017). WUSCHELRELATED HOMEOBOX4 (WOX4)-like genes regulate cambial cell division activity and secondary growth in Populus trees. New Phytol 215, 642-657.

15. Etchells, J.P., and Turner, S.R. (2010). The PXY-CLE41 receptor ligand pair defines a multifunctional pathway that controls the rate and orientation of vascular cell division. Development (Cambridge, England) 137, 767-774.

16. Etchells, J.P., Mishra, L.S., Kumar, M., Campbell, L., and Turner, S.R. (2015). Wood Formation in Trees Is Increased by Manipulating PXY-Regulated Cell Division. Current biology : CB 25, 1050-1055.

17. Fisher, K., and Turner, S. (2007). PXY, a Receptor-like Kinase Essential for Maintaining Polarity during Plant Vascular-Tissue Development. Current biology : CB 17, 1061-1066.

18. Hirakawa, Y., Shinohara, H., Kondo, Y., Inoue, A., Nakanomyo, I., Ogawa, M., Sawa, S., Ohashi-Ito, K., Matsubayashi, Y., and Fukuda, H. (2008). Non-cell-autonomous control of vascular stem cell fate by a CLE peptide/receptor system. Proceedings of the National Academy of Sciences of the United States of America 105, 15208-15213.

19. Morita, J., Kato, K., Nakane, T., Kondo, Y., Fukuda, H., Nishimasu, H., Ishitani, R., and Nureki, O. (2016). Crystal structure of the plant receptor-like kinase TDR in complex with the TDIF peptide. Nature communications 7, 12383.

20. Zhang, H., Lin, X., Han, Z., Qu, L.J., and Chai, J. (2016). Crystal structure of PXY-TDIF complex reveals a conserved recognition mechanism among CLE peptide-receptor pairs. Cell research $26,543-555$.

21. Hirakawa, Y., Kondo, Y., and Fukuda, H. (2010). TDIF peptide signaling regulates vascular stem cell proliferation via the WOX4 homeobox gene in Arabidopsis. Plant Cell 22, 2618-2629.

22. Suer, S., Agustí, J., Sanchez, P., Schwarz, M., and Greb, T. (2011). WOX4 Imparts Auxin Responsiveness to Cambium Cells in Arabidopsis. Plant Cell 23, 3247-3259.

23. Kondo, Y., Ito, T., Nakagami, H., Hirakawa, Y., Saito, M., Tamaki, T., Shirasu, K., and Fukuda, H. (2014). Plant GSK3 proteins regulate xylem cell differentiation downstream of TDIF-TDR signalling. Nature communications 5, 3504. 
24. Saito, M., Kondo, Y., and Fukuda, H. (2018). BES1 and BZR1 Redundantly Promote Phloem and Xylem Differentiation. Plant \& cell physiology 59, 590-600.

25. Brackmann, K., Qi, J., Gebert, M., Jouannet, V., Schlamp, T., Grunwald, K., Wallner, E.S., Novikova, D.D., Levitsky, V.G., Agusti, J., et al. (2018). Spatial specificity of auxin responses coordinates wood formation. Nature communications 9, 875 .

26. Agustí, J., Lichtenberger, R., Schwarz, M., Nehlin, L., and Greb, T. (2011). Characterization of Transcriptome Remodeling during Cambium Formation Identifies MOL1 and RUL1 as Opposing Regulators of Secondary Growth. PLoS Genet 7, e1001312.

27. Gursanscky, N., Jouannet, V., Grünwald, K., Sanchez, P., Laaber-Schwarz, M., and Greb, T. (2016). MOL1 is required for cambium homeostasis in Arabidopsis. The Plant journal : for cell and molecular biology $86,210-220$.

28. Han, S., Cho, H., Noh, J., Qi, J., Jung, H.J., Nam, H., Lee, S., Hwang, D., Greb, T., and Hwang, I. (2018). BIL1-mediated MP phosphorylation integrates PXY and cytokinin signalling in secondary growth. Nature plants 4, 605-614.

29. Merks, R.M., and Glazier, J.A. (2005). A cell-centered approach to developmental biology. Physica A 352, 113-130.

30. Merks, R.M., Guravage, M., Inze, D., and Beemster, G.T. (2011). VirtualLeaf: an open-source framework for cell-based modeling of plant tissue growth and development. Plant physiology $155,656-666$.

31. Brandstadter, J., Rossbach, C., and Theres, K. (1994). The pattern of histone H4 expression in the tomato shoot apex changes during development. Planta 192, 69-74.

32. Sehr, E.M., Agustí, J., Lehner, R., Farmer, E.E., Schwarz, M., and Greb, T. (2010). Analysis of secondary growth in the Arabidopsis shoot reveals a positive role of jasmonate signalling in cambium formation. The Plant journal : for cell and molecular biology 63, 811-822.

33. Wolpert, L. (1969). Positional information and the spatial pattern of cellular differentiation. Journal of theoretical biology 25, 1-47.

34. Mitsuda, N., Iwase, A., Yamamoto, H., Yoshida, M., Seki, M., Shinozaki, K., and Ohme-Takagi, M. (2007). NAC transcription factors, NST1 and NST3, are key regulators of the formation of secondary walls in woody tissues of Arabidopsis. Plant Cell 19, 270-280. 
35. Taylor, N.G., Howells, R.M., Huttly, A.K., Vickers, K., and Turner, S.R. (2003). Interactions among three distinct CesA proteins essential for cellulose synthesis. Proceedings of the National Academy of Sciences of the United States of America 100, 1450-1455.

36. Smith, R.A., Schuetz, M., Roach, M., Mansfield, S.D., Ellis, B., and Samuels, L. (2013). Neighboring parenchyma cells contribute to Arabidopsis xylem lignification, while lignification of interfascicular fibers is cell autonomous. Plant Cell 25, 3988-3999.

37. Sankar, M., Nieminen, K., Ragni, L., Xenarios, I., and Hardtke, C.S. (2014). Automated quantitative histology reveals vascular morphodynamics during Arabidopsis hypocotyl secondary growth. Elife 3, e01567.

38. Driever, W., and Nusslein-Volhard, C. (1988). The bicoid protein determines position in the Drosophila embryo in a concentration-dependent manner. Cell 54, 95-104.

39. Turing, A.M. (1952). The chemical basis of morphogenesis. Phil Trans R Soc B 237, 37-72.

40. Bhalerao, R.P., and Fischer, U. (2014). Auxin gradients across wood - instructive or incidental? Physiologia plantarum 151, 43-51.

41. Etchells, J.P., Provost, C.M., and Turner, S.R. (2012). Plant vascular cell division is maintained by an interaction between PXY and ethylene signalling. PLoS Genet 8, e1002997.

42. Wang, N., Bagdassarian, K.S., Doherty, R.E., Kroon, J.T., Connor, K.A., Wang, X.Y., Wang, W., Jermyn, I.H., Turner, S.R., and Etchells, J.P. (2019). Organ-specific genetic interactions between paralogues of the PXY and ER receptor kinases enforce radial patterning in Arabidopsis vascular tissue. Development (Cambridge, England) 146, dev.177105.

43. Etchells, J.P., Provost, C.M., Mishra, L., and Turner, S.R. (2013). WOX4 and WOX14 act downstream of the PXY receptor kinase to regulate plant vascular proliferation independently of any role in vascular organisation. Development (Cambridge, England) 140, 2224-2234.

44. Gujas, B., Kastanaki, E., Sturchler, A., Dias Cruz, T.M., Ruiz-Sola, M.A., Dreos, R., Eicke, S., Truernit, E., and Rodriguez-Villalon, A. (2020). A reservoir of pluripotent phloem cells safeguards the linear developmental trajectory of protophloem sieve elements. Current biology : CB 30.

45. Wunderling, A., Ripper, D., Barra-Jimenez, A., Mahn, S., Sajak, K., Targem, M.B., and Ragni, L. (2018). A molecular framework to study periderm formation in Arabidopsis. New Phytol 219, 216-229. 
46. Spicer, R., and Groover, A. (2010). Evolution of development of vascular cambia and secondary growth. New Phytol 186, 577-592.

47. Carlquist, S. (2007). Successive Cambia Revisited: Ontogeny, Histology, Diversity, and Functional Significance. The Journal of the Torrey Botanical Society 134, 301-332.

48. Pace, M.R., Lohmann, L.G., and Angyalossy, V. (2009). The rise and evolution of the cambial variant in Bignonieae (Bignoniaceae). Evolution \& development 11, 465-479.

49. Bhalerao, R.P., and Fischer, U. (2017). Environmental and hormonal control of cambial stem cell dynamics. Journal of experimental botany $68,79-87$.

50. Gerttula, S., Zinkgraf, M., Muday, G.K., Lewis, D.R., Ibatullin, F.M., Brumer, H., Hart, F., Mansfield, S.D., Filkov, V., and Groover, A. (2015). Transcriptional and Hormonal Regulation of Gravitropism of Woody Stems in Populus. Plant Cell 27, 2800-2813.

51. Agustí, J., Herold, S., Schwarz, M., Sanchez, P., Ljung, K., Dun, E.A., Brewer, P.B., Beveridge, C.A., Sieberer, T., Sehr, E.M., et al. (2011). Strigolactone signaling is required for auxindependent stimulation of secondary growth in plants. Proc Natl Acad Sci USA 108, 2024220247.

52. Wallner, E.S., Lopez-Salmeron, V., Belevich, I., Poschet, G., Jung, I., Grunwald, K., Sevilem, I., Jokitalo, E., Hell, R., Helariutta, Y., et al. (2017). Strigolactone- and Karrikin-Independent SMXL Proteins Are Central Regulators of Phloem Formation. Current biology : CB 27, 1241-1247.

53. Hellens, R.P., Edwards, E.A., Leyland, N.R., Bean, S., and Mullineaux, P.M. (2000). pGreen: a versatile and flexible binary Ti vector for Agrobacterium-mediated plant transformation. Plant molecular biology 42, 819-832.

54. Haseloff, J., Siemering, K.R., Prasher, D.C., and Hodge, S. (1997). Removal of a cryptic intron and subcellular localization of green fluorescent protein are required to mark transgenic Arabidopsis plants brightly. Proceedings of the National Academy of Sciences of the United States of America 94, 2122-2127.

55. Sommer, C., Strähle, C., Köthe, U., and Hamprecht, F.A. (2011). ilastik: Interactive Learning and Segmentation Toolkit. In Eighth IEEE International Symposium on Biomedical Imaging (ISBI). Proceedings. pp. 230-233.

56. Merks, R.M., and Guravage, M.A. (2013). Building simulation models of developing plant organs using VirtualLeaf. Methods Mol Biol 959, 333-352. 
bioRxiv preprint doi: https://doi.org/10.1101/2020.01.16.908715; this version posted January 17, 2020. The copyright holder for this preprint (which was not certified by peer review) is the author/funder, who has granted bioRxiv a license to display the preprint in perpetuity. It is made available under aCC-BY-NC 4.0 International license.

Lebovka et al.

57. Bergstra, J., Yamins, D., and Cox, D.D. (2013). Making a Science of Model Search: Hyperparameter Optimization in Hundreds of Dimensions for Vision Architectures, (Atlanta, GA, USA: JMLR.org). 

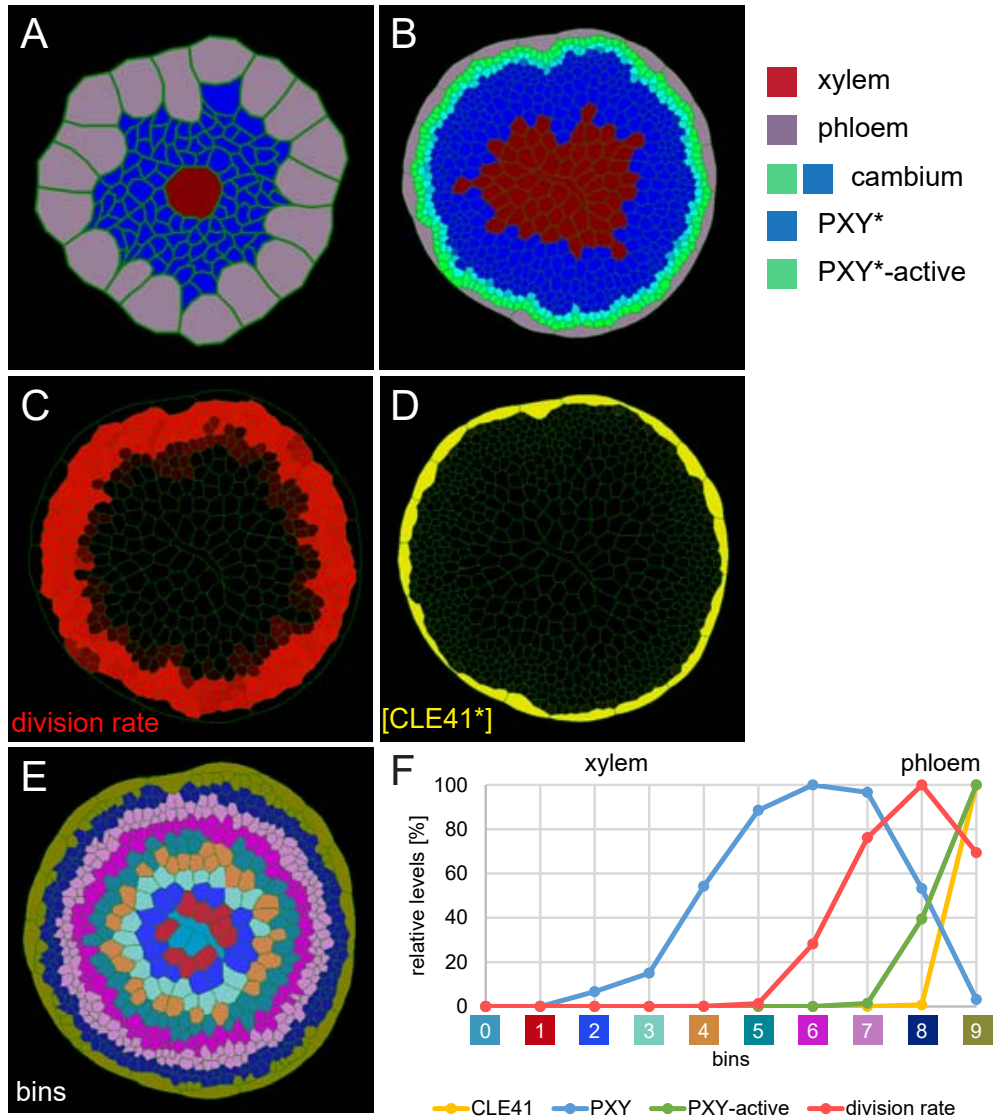

$\rightarrow$ CLE41 $\rightarrow$ PXY $\rightarrow$ PXY-active $\rightarrow$ division rate

Figure 1. Initial model generation. (A) Tissue template used to run VirtualLeaf simulations. Phloem ${ }^{*}$ is depicted in purple, xylem* in red. Cambium* cells are colored according to their levels of $P X Y^{*}$ and $P X Y$-active*. Cambium* is colored in blue due to the initial level of $P X Y^{*}$. (B) Output of simulation using Model 1. (C) Visualization of cell division rates within the output shown in (B). Dividing cells are marked by a red color which fades over time. (D) Visualization of CLE41* levels within the output shown in (B). (E) Sorting cells* within the output shown in (B) into bins based on how far their centers are from the center of the hypocotyl ${ }^{*}$. Different colors represent different bins. (F) Visualization of the relative chemical levels and division rates in different bins shown in (E). Each chemical's bin average is calculated and then expressed as a percentage of the maximum bin value of the chemical. Bin colors along the x-axis correspond to the colors of bins in (E). 

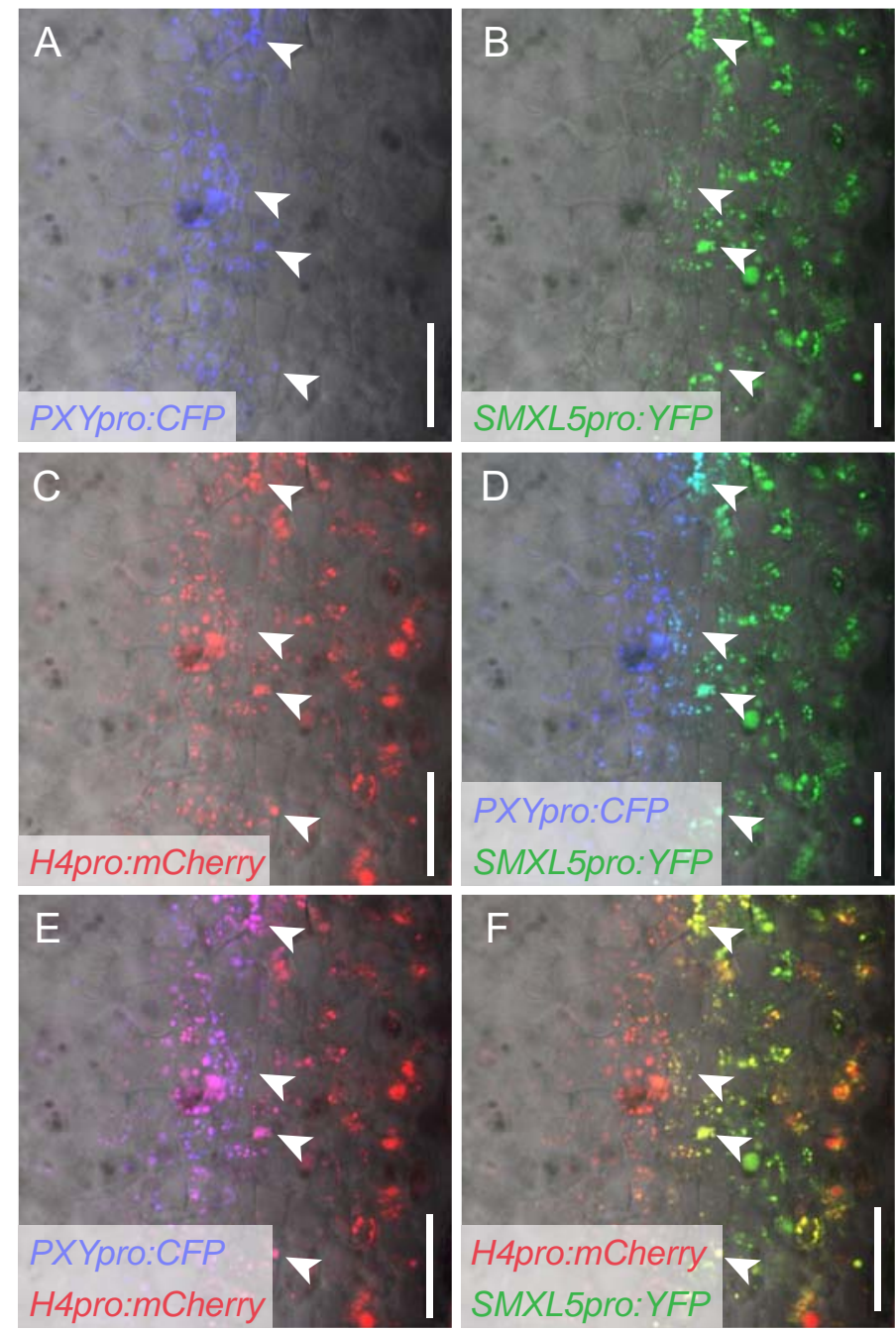

Figure 2. Visualization of $\mathrm{H4}$ promoter activity within cambium subdomains. (A-F) PXYpro:CFP (blue) and SMXL5pro:YFP (green) activities mark proximal $(A)$ and distal $(B)$ cambium subdomains, respectively, and show only a small overlap ( $D$, arrows). The overlap of signals from the H4pro:mCherry (red) (C) and proximal (E) and distal $(F)$ cambium markers indicate the presence of cell in the S-phase in both subdomains. Arrows point to the same position in each picture. Scale bars: $50 \mu \mathrm{m}$. 

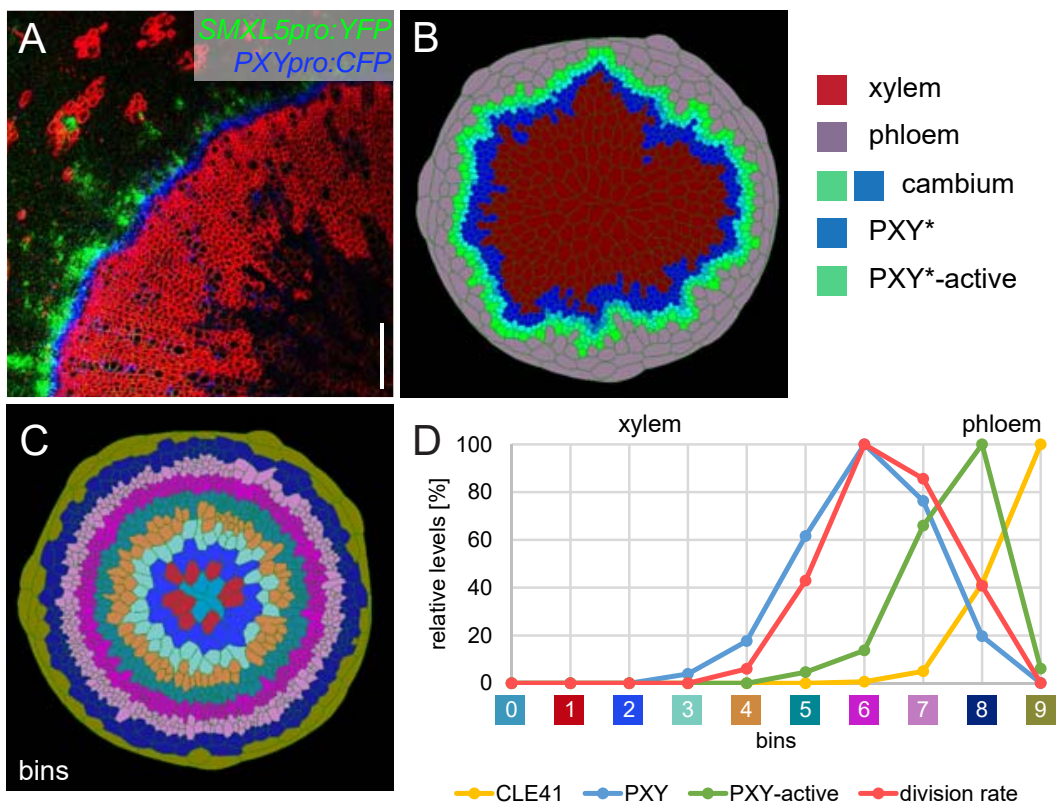

Figure 3. Implementing phloem formation into the model. (A) Cross-section of a wild type hypocotyl expressing PXYpro:CFP (blue) and SMXL5pro:YFP (green). Cell walls are stained by propidium iodide, mainly visualizing xylem (red). Only a quarter of the hypocotyl is shown with the center in the bottom right corner. Scale bar: $100 \mu \mathrm{m}$. (B) Output of simulation using Model 2A. Unlike Model 1, Model 2A produces new phloem* cells. (C) Sorting cells* within the output shown in (B) into bins. (D) Visualization of the relative chemical levels and division rates in different bins shown in $(C)$. Bin label colors along the $x$-axis correspond to the colors of bins shown in (C). 

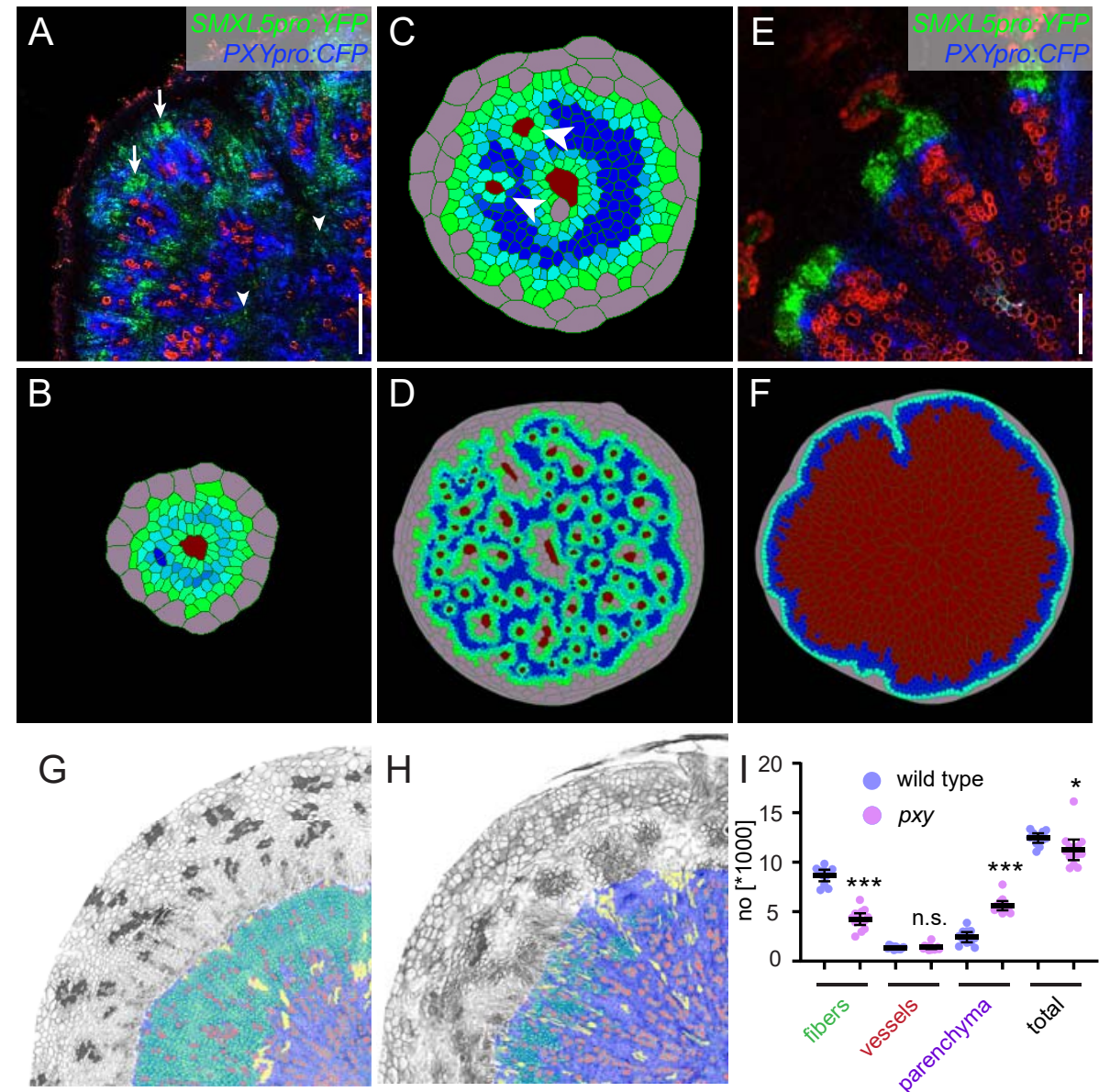

Figure 4. Comparing the effect of perturbing cambium activity in the model and in plants. (A) Cross-section of a hypocotyl carrying PXYpro:CFP (blue), SMXL5pro:YFP (green) markers, and the IRX3pro:CLE41 transgene. Cell walls are stained by propidium iodide visualizing mostly xylem (red). Arrowheads point to proximal hypocotyl regions where SMXL5pro:YFP activity is found. Arrows indicate distal regions with SMXL5pro:YFP activity. Cell walls are stained by propidium iodide visualizing mostly xylem (red). Only a quarter of the hypocotyl is shown with the center in the bottom right corner. Scale bar: $100 \mu \mathrm{m}$. (B) First frames of Model 2B simulations. Due to the expression of CLE41* by xylem* cells, high levels of PXY-active* are generated around xylem cells* already at this early stage. (C) Intermediate frames of Model 2B simulations. Newly formed xylem cells* express CLE41* and produce high levels of PXY-active* next to them (white arrowheads). (D) The final result of Model 2B simulations. Zones of PXY* (blue) and PXY-active* (green) are intermixed, xylem* cells are scattered, and phloem* cells are present in proximal areas of the hypocotyl*. (E) Cross-section of a pxy mutant hypocotyl carrying PXYpro:CFP (blue) and SMXL5pro:YFP (green) markers, stained by propidium iodide (red). The xylem shows a ray-like structure. Only a quarter of the hypocotyl is shown with the center in the bottom right corner. Scale bar: $100 \mu \mathrm{m}$. (F) Final result of Model $2 \mathrm{C}$ simulations. Reducing $\mathrm{PXY} \mathrm{Y}^{*}$ levels leads to similar results as produced by Model 1 (Figure 1B) where only xylem* is produced. (G, H) Comparison of histological cross-sections of a wild type $(\mathrm{G})$ and a pxy $(\mathrm{H})$ mutant hypocotyl, including cell type classification produced by ilastik. The ilastik classifier module was trained to identify xylem vessels (red), fibers (green), and parenchyma (purple), unclassified objects are shown in yellow. (I) Comparison of the number of xylem vessels, fibers and parenchyma cells found in wild type (blue) and pxy mutants (purple). Welch's $t$ test was performed comparing wild-type and pxy mutants for the different cell types $(n=$ $11-13) .{ }^{* *} p<0.0001,{ }^{*} p<0.05$. Lines indicate means with a $95 \%$ confidence interval. 

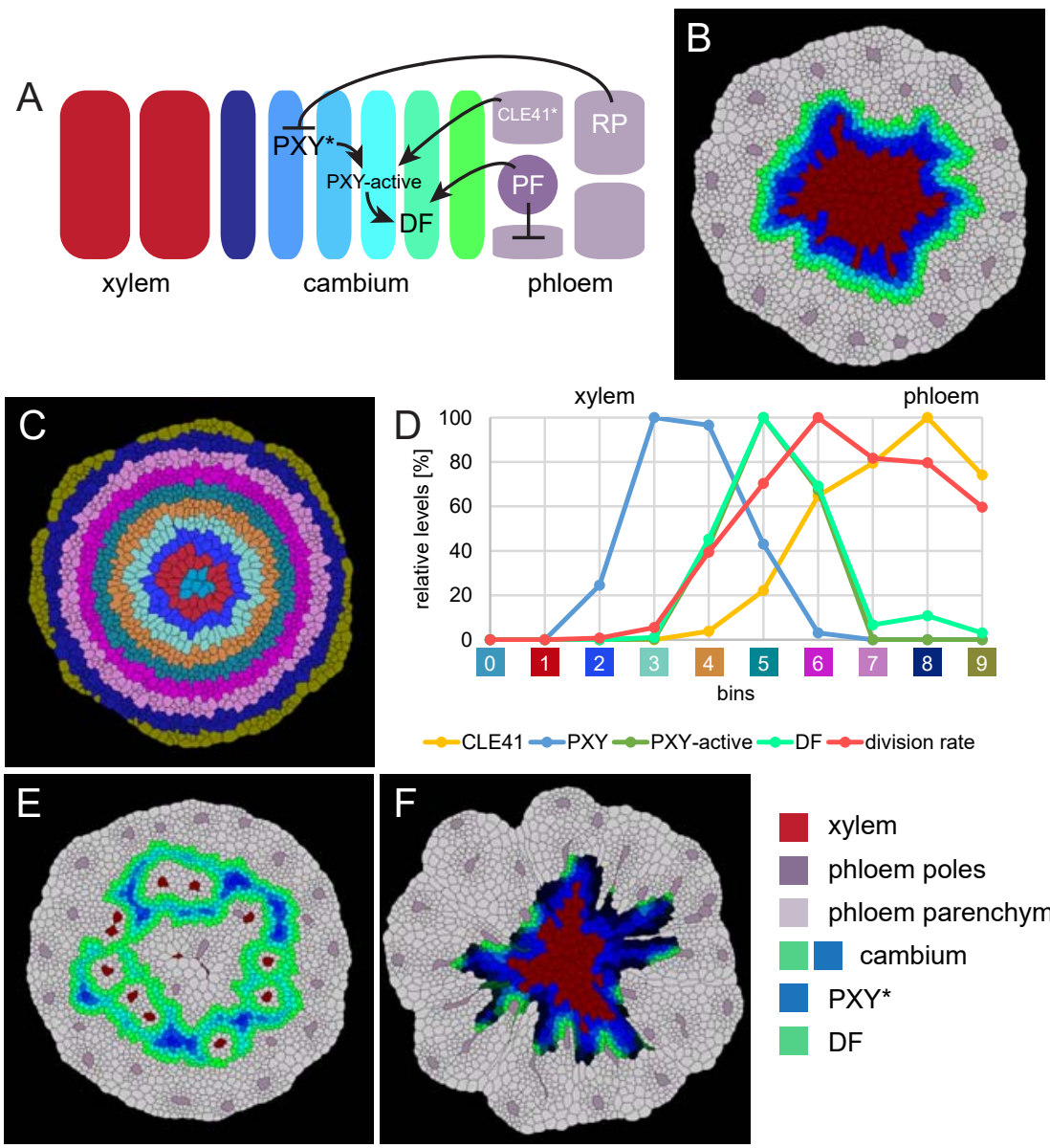

\begin{tabular}{|c|c|c|c|c|c|c|c|}
\hline \multirow[t]{2}{*}{ Cell type } & \multicolumn{2}{|c|}{$\begin{array}{l}\text { Starting } \\
\text { template }\end{array}$} & \multicolumn{2}{|c|}{\begin{tabular}{|l} 
Intitial values \\
(after run)
\end{tabular}} & \multicolumn{2}{|c|}{$\begin{array}{l}\text { New values } \\
\text { (after run) }\end{array}$} & \multirow{2}{*}{$\begin{array}{c}\text { in planta } \\
\text { values } \\
\%\end{array}$} \\
\hline & counts & $\%$ & counts & $\%$ & counts & $\%$ & \\
\hline Cambium cells ${ }^{*}$ & 95 & 62.5 & 406 & 27.7 & 660 & 27 & 24 \\
\hline Xylem cells* & 1 & 0.7 & 97 & 6.6 & 227 & 9.3 & 10 \\
\hline Phloem pole cells & 2 & 1.3 & 16 & 1.1 & 25 & 1 & 65 \\
\hline $\begin{array}{l}\text { Phloem } \\
\text { parenchyma cells* }\end{array}$ & 54 & 35.5 & 947 & 64.6 & 1531 & 62.7 & \\
\hline total & 152 & 100 & 1466 & 100 & 2443 & 100 & 100 \\
\hline
\end{tabular}

Figure 5. An extended model for simulating genetic perturbations. (A) Regulatory network proposed based on experimental observations. (B) Result of the simulation run for Model 3A. This model implements the network interactions described in (A). (C) Outline of cell bins for the results of Model 3A, as shown in (B). (D) Visualization of the relative levels of chemicals and division rates in different bins. Bin colors along the $x$-axis correspond to the bin colors in (C) (E) Output of Model 3B simulation. Ectopic CLE41* expression was achieved by letting xylem cells* produce CLE41*. (F) Output of Model 3C. Simulation of the pxy mutant was achieved by removing the stimulation of $\mathrm{DF}^{*}$ production by $\mathrm{PXY}^{*}$ and hence by removing the effect of $P X Y^{*}$ on cell division and cambium* subdomain patterning. Because of the network structure, $P X Y^{*}$ can be eliminated from Model 3 without letting the model collapse (Fig. 4F) but reproducing the pxy mutant phenotype observed in adult hypocotyls (Fig. 4E). (G) Comparison of numbers and proportions of distinct cells* in the initial tissue template (as shown in Fig. $1 \mathrm{~A}$, in green) with the final model output before the automated parameter search (as shown in Figure 5B, in blue) and the model output after the parameter search (in orange). In yellow, values found for wild type (Col-0) hypocotyls 20 days after germination [37] are depicted. 

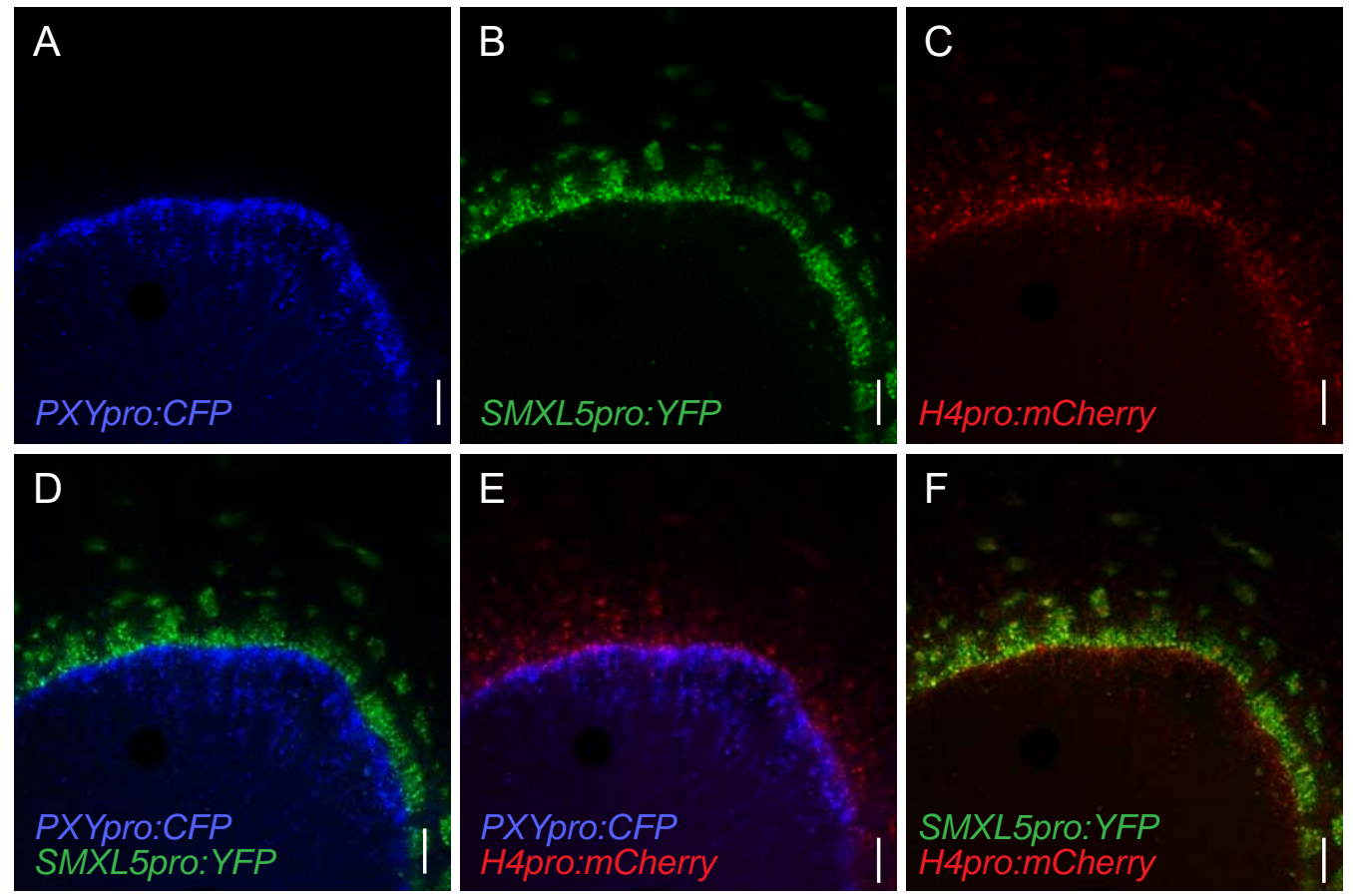

Figure S1. Visualization of $H 4$ promoter activity within cambium subdomains. (A-F) $P X Y$ pro:CFP and SMXL5pro:YFP mark proximal (A) and distal (B) cambium subdomains, respectively. H4pro:mCherry (C) is used as a marker for cells in the S-phase. The overlay of signals of H4pro:mCherry and proximal $(E)$ and distal $(F)$ cambium markers indicates cell division in both subdomains. Scale bars: $100 \mu \mathrm{m}$. 
Table S1: Parameters aperpettity itcis made available under aCC-BY-NC 4.0 International license.

\begin{tabular}{|l|l|r|r|}
\hline index & function & before search & after search \\
\hline k0 & chemical 6 limit above which parenchyma cell can divide & $1.00 \mathrm{E}-04$ & $9.28 \mathrm{E}-05$ \\
\hline k1 & xylem max cell size & $1.00 \mathrm{E}+00$ & $1.43 \mathrm{E}+00$ \\
\hline k2 & not used & $1.00 \mathrm{E}+01$ & $1.87 \mathrm{E}+01$ \\
\hline k3 & not used & $2.30 \mathrm{E}+00$ & $6.05 \mathrm{E}+00$ \\
\hline k4 & chemical 5 limit below which parenchyma can convert to phloem pole & $1.00 \mathrm{E}-06$ & $1.80 \mathrm{E}-06$ \\
\hline k5 & chemical 6 limit above which cambium cell can turn into parenchyma & $2.40 \mathrm{E}-02$ & $6.53 \mathrm{E}-02$ \\
\hline k6 & chemical 6 limit above which cambium cell can divide & $1.00 \mathrm{E}-04$ & $6.27 \mathrm{E}-05$ \\
\hline k7 & phloem parenchyma max cell size & $3.00 \mathrm{E}+00$ & $8.38 \mathrm{E}+00$ \\
\hline k8 & size above which parenchyma is converted to phloem poles & $1.50 \mathrm{E}+00$ & $1.55 \mathrm{E}+00$ \\
\hline k9 & phloem pole max cell size & $3.00 \mathrm{E}+00$ & $5.83 \mathrm{E}+00$ \\
\hline k10 & cambium cell max cell size & $2.30 \mathrm{E}+00$ & $4.62 \mathrm{E}+00$ \\
\hline k11 & cambium cell size limit above which it can convert to xylem & $1.90 \mathrm{E}+00$ & $1.20 \mathrm{E}+00$ \\
\hline k12 & chemical 1 limit above which cambium cell can convert into xylem & $8.00 \mathrm{E}+00$ & $7.82 \mathrm{E}+00$ \\
\hline k13 & rate of how much chemical 4 supress expression of pxy & $1.00 \mathrm{E}+02$ & $2.87 \mathrm{E}+02$ \\
\hline k14 & not used & $4.80 \mathrm{E}+01$ & $5.51 \mathrm{E}+01$ \\
\hline k15 & cell size above which parenchyma cell can divide & $1.00 \mathrm{E}+00$ & $6.70 \mathrm{E}-01$ \\
\hline k16 & cell size above which cambium cell can divide & $1.00 \mathrm{E}+00$ & $8.19 \mathrm{E}-01$ \\
\hline k17 & $\begin{array}{l}\text { defines saturation curve for chemical 6 (so chemical 6 concetration is } \\
\text { restricted from above) }\end{array}$ & $1.42 \mathrm{E}-02$ & $2.35 \mathrm{E}-02$ \\
\hline k18 & $\begin{array}{l}\text { defines saturation curve for chemical 6 (so chemical 6 concetration is } \\
\text { restricted from above) }\end{array}$ & $1.39 \mathrm{E}+01$ & $3.44 \mathrm{E}+01$ \\
\hline k19 & cle41 production rate in phloem parenchyma & $1.00 \mathrm{E}-01$ & $1.01 \mathrm{E}-01$ \\
\hline k20 & Cle41 production rate in phloem poles & $1.00 \mathrm{E}+00$ & $1.87 \mathrm{E}+00$ \\
\hline k21 & $\begin{array}{l}\text { rate of how much input pxy makes in stimulating production of } \\
\text { chemical 6 (rate 0 would be pxy mutant) }\end{array}$ & $1.00 \mathrm{E}+02$ & $1.43 \mathrm{E}+02$ \\
\hline
\end{tabular}

\begin{tabular}{|r|l|}
\hline chemicals \\
\hline 0 & cle41 \\
\hline 1 & pxy free \\
\hline 2 & pxy active \\
\hline 3 & PROMOTES DIVISION CHEMICAL (COMES FROM PHLOEM \\
\hline 3 & POLES) \\
\hline 4 & SUPRESSES PXY EXPRESSION (COMES FROM ALL PHLOEM \\
\hline 5 & SUPRESSES PHLOEM POLE FORMATION (COMES FROM \\
\hline 6 & PHLOEM POLES) \\
\hline & DIVISION CHEMICAL \\
\hline
\end{tabular}




\section{Supplemental Methods:}

\section{Instructions for implementing VirtualLeaf models}

To be able to see established models in action, the VirtualLeaf software should be installed according to the following instructions and as described previously [1]. There are three files to be installed to view a model. For each model described in this paper, we provide these three files in the "model_codes" folder found at https://github.com/kergakerga/cambium_models.

\section{Model.h}

This is a c++ header file containing a line with the following structure: "this:virtual QString DefaultLeafML(void) \{return QString("hypo7.xml");\}". The line indicates where VitualLeaf should search for an $\mathrm{xml}$ file that describes the structure of the tissue template (called "leaf") used for the model to run upon. In this particular example, the name of the xml template is "hypo7.xml". VirtualLeaf will go to the folder in which you installed the software and will look for this file in the subfolder "../data/leaves". In our case, a Windows machine was used. Therefore, the full path looked like this: "C:IVirtualLeaf-v1.0-srcldatalleaves" and this folder contained a file "hypo7.xml". Please note that paths will be different depending on the operating system being used.

\section{Model.cpp}

A c++ file containing the model algorithm to reproduce the output described in this study. A formal description of each model was given within the main text. 


\section{Leaf.xml}

A file containing the description of a tissue template as described before [2]. The software uses this file to construct a tissue template and to run a given model.

In order to run or modify a provided model, follow the following instructions.

a. Create a new model with the desired name (e.g. "my_cool_model") as described [2].

b. After a new model was created, there should be a folder "../src/my_cool_model” in your VirtualLeaf folder. In our case, the full path looked like this: "C:IVirtualLeaf-v1.0srclsrclTutorialCodelmy_cool_model”.

c. In your “../src/TutorialCode/my_cool_model” folder locate "my_cool_model.h" and "my_cool_model.cpp" files. Using a text editor replace the content of those files by the content of the respective files from the model you are interested in (files provided in this paper are called "uncoupleCle.h" and "uncoupleCle.cpp"). Please note that you should only replace the content of the files and not the files themselves. After you have completed this step, your files should still be named "my_cool_model.h" and "my_cool_model.cpp".

d. Open the files "my_cool_model.h" and "my_cool_model.cpp" using a text editor and replace every instance of "uncoupleCle" by "my_cool_model" in the text. Save the changes.

e. Locate the "../data/leaves" folder and add the provided xml file defining the tissue template (in our case, the tissue template is called "hypo7.xml'). The resulting full path to the file had the following structure in our case: "C:IVirtualLeaf-v1.0srcldatalleaveslhypo7.xml”.

f. Compile the model as described [2]. In our case, we used a qt-console, switched to the folder with the model (make sure your VL is not running): "C:IVirtualLeaf-v1.0srclsrclTutorialCodelmy_cool_model" and run "set MAKE=mingw32-make" and 
"mingw32-make". Please note that each time you introduce changes into the code, you should recompile the model.

g. Now you can run VirtualLeaf. Go to the “../bin' folder and run the "VirtualLeaf” file. In our case the full path looked like this: "C:IVirtualLeaf-v1.0-srclbinIVirtualLeaf ".

The new model will appear under the "Models" section with the corresponding name. Please note that the name of the model that will be shown is not the same as "my_cool_model". Instead, it will show whichever name was indicated in the "my_cool_model.cpp" file in this line: // specify the name of your model here; return QString( "Model 1 - pxy only" )". In this case, there will be a new model called "Model 1 - pxy only" in the VirtualLeaf folder under the "Models" section.

\section{Literature}

1. Merks, R.M., and Guravage, M.A. (2013). Building simulation models of developing plant organs using VirtualLeaf. Methods Mol Biol 959, 333-352.

2. Merks, R.M., Guravage, M., Inze, D., and Beemster, G.T. (2011). VirtualLeaf: an open-source framework for cell-based modeling of plant tissue growth and development. Plant physiology $155,656-666$. 